\title{
INFLUENCE OF HARVEST TIME ON THE PHENOLIC CONTENT OF HORSERADISH LEAVES
}

\author{
Lolita Tomsone*, Zanda Kruma \\ Department of Food Technology, Faculty of Food Technology, Latvia University of Agriculture, Rigas iela 22, Jelgava, Latvia, \\ e-mail:lolita.tomsone@llu.lv
}

\begin{abstract}
A perennial herb horseradish (Armoracia rusticana L.) contains biologically active substances and cultivated in temperate regions of the world. The aim of the current research was to determine the content of phenolic compounds and antioxidant properties of horseradish leaves depending on the harvest time. For experiments horseradish leaves three years at six different times (during the period from May to October) were collected. Fresh plant material was extracted with ethanol using conventional extraction. For all

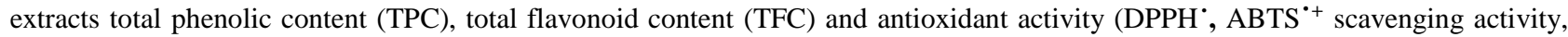
reducing power) were determined using a spectrophotometric methods. Results showed that content of phenolic compounds and antioxidant activity of horseradish leaves were significantly affected by harvest time. The highest TPC and $\mathrm{ABTS}^{\circ}+\mathrm{scavenging}^{-}$ activity was observed in the horseradish leaves collected in May, but the highest TFC and antioxidant activity (DPPH radical scavenging activity and reducing power) was observed in June. The content of phenolics compounds and antioxidant activity significantly decreased during post flowering stage and continues till October. Horseradish leaves contained considerable amount of phenolics compounds and natural antioxidants. In further experiments, use of horseradish leaves as natural antioxidants in different food matrixes should be studied.
\end{abstract}

Keywords: horseradish, harvest time, phenolic, antioxidant.

\section{Introduction}

Plants are rich in natural antioxidants, which are very important for human health (Naczk, Shahidi, 2006). The antioxidant characteristics of plant raw materials can be attributed to their phenolic compounds. Chemically phenolic compounds are highly active substances and over the past twenty years their popularity as natural antioxidants has grown significantly (Kammerer, Carle, 2012; Naczk, Shahidi, 2003).

Biologically active substances, especially phenolic compounds, composition, content and function in plants is affected by different factors - harvest time, various external factors (cultivation, storage conditions, processing, climate), genetic background (variety, genotype) (Angela, Meireles, 2009; Marrelli et al., 2012). Plants phenolic compounds are synthesized in a normal stage of development, but they increasingly can be synthesized by biotic or abiotic stress conditions (ultra-violet (UV) radiation, mechanical injury or microbial infection) (Naczk, Shahidi, 2006). Different plant enzymatic systems, which are involved in the biosynthesis of phenols, vary the profiles significantly (Hilt et al., 2003), thereby the phenols have wide variations in function (Kammerer, Carle, 2012).

The plants development stage at harvest time is an important factor of product quality. Several authors have reported that antioxidant activity (AA) and chemical composition are influenced by the harvest time, as well as the content of compounds and properties vary from plant development stages (Imene et al., 2012; Tomsone et al., 2012; Marrelli et al., 2012). The content and composition of phenolic compounds and antioxidant potential of areal parts of Calamintha nepeta L. Savi (Lamiaceae) was significantly affected by ontogenic growth stages (Pacifico et al., 2015). Tunisian researchers have found that for some plants (O. ficus-indica (L.) Mill. and O. stricta (Haw.) Haworth) significantly higher total phenolics content (TPC) and AA are directly during flowering (Imene et al., 2012), similar trend also was observed for phenolic compounds in horseradish roots (Tomsone et al., 2012). Whereas the lowest TPC of Ficus caricacv. 'Dottato' fruit was at the beginning of maturation and gradually increased with the pulp ripening stage (Marrelli et al., 2012). Such differences might be related to changes in the secondary metabolism (Imene et al., 2012).

Horseradish (Armoracia rusticana L.) belong to Brassicaceae family. There is few found data about phenolic quantitative content of horseradish in the literature. One of the studies showed that TPC of horseradish leaves ranged from $256 \mathrm{mg}$ GAE $100 \mathrm{~g}^{-1} \mathrm{DW}$ to $385 \mathrm{mg}$ GAE $100 \mathrm{~g}^{-1} \mathrm{DW}$ (Calabrone et al., 2015). That is significantly more than the kale (Lathyrus L.), spinach (Spinacia L.) and broccoli (Bromelia L.), but less than the potato (Kochia scoparia L.) and carrot (Bromelia L.) (Zhou et al., 2006). The plants of Brassicaceae contain a number of compounds that can act as natural antioxidants (Raghavan, 2000). Several authors reported that also the chemical composition of Brassicaceae plants varies depending on the harvest time, growing conditions (Kusznierewicz et al., 2008) and stage of development (Björkman et al., 2011).

The aim of the current research was to determine the content of phenolic compounds and antioxidant properties of horseradish leaves depending on harvest time.

\section{Materials and Methods \\ Chemicals}

Gallic acid, Folin-Ciocalteu phenol reagent, and 2,2diphenyl-1-picrylhydraziyl (DPPH $\left.{ }^{*}\right)$ were purchased from Sigma-Aldrich (Switzerland). All other chemicals 
$\left(\mathrm{Na}_{2} \mathrm{CO}_{3}\right.$, ethanol) used in the research were obtained from Acros Organic (USA).

\section{Sample preparation}

Fresh samples were collected from May to October in Jelgava Latvia during three-year period (2014-2016). Average temperature and precipitation during study in harvest place are shown in Figure 1.

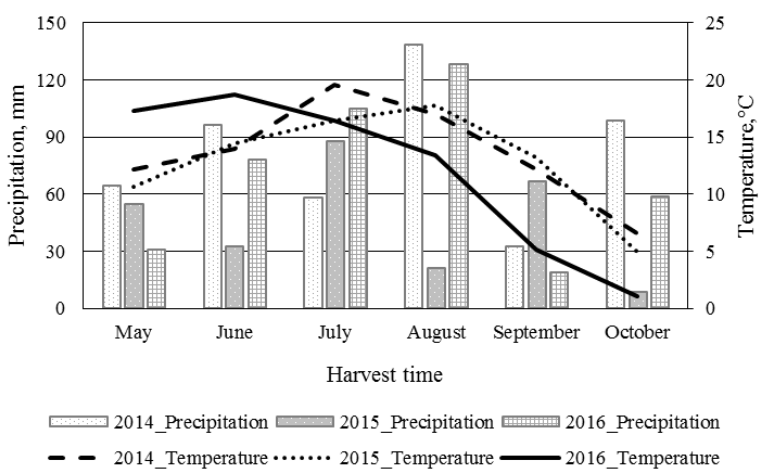

Figure 1. Average temperature and precipitation

Characterization of collected horseradish leaves are shown in Table 1.

Table 1

Height of collected horseradish plants, $\mathrm{cm}$

\begin{tabular}{lccc}
\hline Harvest times & $\mathbf{2 0 1 4}$ & $\mathbf{2 0 1 5}$ & $\mathbf{2 0 1 6}$ \\
\hline May & $10-15$ & $10-14$ & $9-14$ \\
June & $14-20$ & $12-21$ & $13-20$ \\
July & $15-28$ & $17-30$ & $13-26$ \\
August & $17-33$ & $17-38$ & $18-33$ \\
September & $20-45$ & $18-44$ & $22-40$ \\
October & $24-50$ & $27-53$ & $27-52$ \\
\hline
\end{tabular}

Extraction procedure

Extraction procedure was applied as outlined by Tomsone et al. (2012). The extraction process was done in triplicate.

\section{Analytical methods}

Determination of total phenolic content (TPC) and total flavonoid content (TFC). The TPC of the plant extract was determined according to the Folin-Ciocalteu spectrophotometric method (Singleton et al., 1999). TPC was expressed as the gallic acid equivalents (GAE) $100 \mathrm{~g}^{-1}$ dry weight (DW) of plant material. The TFC was measured by a colorimetric method (Kim et al., 2003). TFC was expressed as the catehin equivalents (CE) $100 \mathrm{~g}^{-1} \mathrm{DW}$ of plant material.

Determination of antioxidant activity (AA). AA of the plant extracts was measured on the basis of scavenging activities of the stable 2,2-diphenyl-1-picrylhydraziyl $\left(\mathrm{DPPH}^{\circ}\right)$ radical as outlined by $\mathrm{Yu}$ et al. (2003). The radical scavenging activity of extract was also measured by $2,2^{\prime}$-azino-bis(3-ethylbenz-thiazoline-6sulfonic) acid $\left(\mathrm{ABTS}^{\circ}\right)$ cation assay (Re et al., 1999). The radical scavenging activity was expressed as TE $100 \mathrm{~g}^{-1} \mathrm{DW}$ of plant material. The higher the Trolox equivalent antioxidant capacity (TEAC) of a sample, the stronger the antioxidant activity. The reducing power was determined by the method of Athukorala et al. (2006) and reducing power was expressed as the ascorbic acid equivalents (AAE) $100 \mathrm{~g}^{-1} \mathrm{DW}$ of plant material. Additionally for all horseradish leaves samples the moisture content was determined according to the standard ISO 6496:1999 and all results were expressed on dry basis.

Statistical analysis

Experimental results are means of three parallel measurements and were analysed by Microsoft Excel 2010 and SPSS 17.00. Analysis of variance (ANOVA) and Tukey's test were used to determine differences among samples. A linear correlation analysis was performed in order to determine relationship between TPC, TFC, antioxidant activity such as DPPH', $\mathrm{ABTS}^{\circ+}$ and reducing power. Differences were considered as significant at $\mathrm{p}<0.05$.

\section{Results and Discussion}

Total phenolics and flavonoids content

The TPC determined in horseradish leaves depending on harvest time are shown in Table 2. ANOVA analysis of variance showed that TPC was significantly affected $(p<0.05)$ by harvest time but not by harvest year.

Table 2

Total phenolic content of horseradish leaves at different harvest times, mg GAE $100 \mathrm{~g}^{-1} \mathrm{DW}$

\begin{tabular}{lccc}
\hline $\begin{array}{l}\text { Harvest } \\
\text { times }\end{array}$ & $\mathbf{2 0 1 4}$ & $\mathbf{2 0 1 5}$ & $\mathbf{2 0 1 6}$ \\
\hline May & $2634 \pm 57^{\mathrm{a}^{*}, \mathrm{~A}^{* *}}$ & $2705 \pm 59^{\mathrm{a}, \mathrm{A}}$ & $2590 \pm 55^{\mathrm{a}, \mathrm{A}}$ \\
June & $2368 \pm 52^{\mathrm{b}, \mathrm{A}}$ & $2351 \pm 53^{\mathrm{b}, \mathrm{A}}$ & $2339 \pm 50^{\mathrm{b}, \mathrm{A}}$ \\
July & $1853 \pm 56^{\mathrm{c}, \mathrm{A}}$ & $1834 \pm 50^{\mathrm{c}, \mathrm{A}}$ & $1814 \pm 54^{\mathrm{c}, \mathrm{A}}$ \\
August & $1568 \pm 50^{\mathrm{d}, \mathrm{A}}$ & $1616 \pm 52^{\mathrm{d}, \mathrm{A}}$ & $1642 \pm 48^{\mathrm{d}, \mathrm{A}}$ \\
September & $1339 \pm 59^{\mathrm{e}, \mathrm{A}}$ & $1380 \pm 51^{\mathrm{e}, \mathrm{A}}$ & $1368 \pm 58^{\mathrm{e}, \mathrm{A}}$ \\
October & $1279 \pm 54^{\mathrm{e}, \mathrm{A}}$ & $1235 \pm 51^{\mathrm{f}, \mathrm{A}}$ & $1252 \pm 50^{\mathrm{e}, \mathrm{A}}$ \\
\hline
\end{tabular}

* Different small letters in the same column represents significant differences between values (Tukey's test, $\mathrm{p}<0.05$ ). ** Different capital letters in the same row represents significant differences between values (Tukey's test, $\mathrm{p}<0.05$ ).

Comparing harvest years similar tendency in all analysed samples was observed - the highest TPC was in May and by October it gradually decreased by $52 \%$ on average. No significant differences between TPC of horseradish leaves collected in May 2014, 2015 and 2016 were determined while comparing weather conditions - in May 2015 there was the lowest average air temperature $\left(+10.6^{\circ} \mathrm{C}\right)$, compared with $2014\left(+12.2{ }^{\circ} \mathrm{C}\right)$ and $2016\left(+17.3{ }^{\circ} \mathrm{C}\right)$. Environmental stress conditions (heat, cold, ozone, drought, intense light before the harvest) have a positive impact on the TPC in fruit and vegetables - lettuce (Leucojum vernum L.), for sweet potatoes (Salix L.), strawberries (Zantedeschia aethiopica L.), tomatoes and maize (Kniphofiauvaria L.) (Capanoglu, 2010).

A group of researchers found that content of phenolic acids (for example caffeic acid) of areal parts of Calamintha nepeta L. Savi was significantly higher at the flowering stage than at the post flowering stage (Pacifico et al., 2015).There is no general tendency for differences of TPC in horseradish roots depending on genotype and harvest time (Tomsone et al., 2012). 
The highest TFC (Table 3) was determined in June 2016, when the average air temperature was higher $\left(+18.7^{\circ} \mathrm{C}\right) \quad$ compared to $2014 \quad\left(+14.0^{\circ} \mathrm{C}\right)$ and $2015\left(+14.4^{\circ} \mathrm{C}\right)$. The TFC in July decreased on average by $37 \%$. This may be due to the intensity of UV radiation, influenced by the daylight hours and ontogenic growth stages of plants. There was a tendency, that after June to October (during post flowering stage) TFC in horseradish leaves gradually decreased by an average of $76 \%$ in three analysed years.

Flavones and flavonols are highly UV absorbers, which accumulates mainly in the cells of the epidermis. Consequently, in different parts of one plant is significantly different flavonoid content and leaves contain more flavonoids than roots (Gould, Lister, 2006; Naczk, Shahidi, 2003).

The obtained results showed that the largest content of phenolic compounds of horseradish leaves was in the period from May to June, which coincides with the horseradish development period until the flowering and the flowering period (Raghavan, 2000). A similar trend was also observed in $W$. somnifera leaves (Fernando et al., 2013). The phenolic compounds synthetic reinforced surface plant parts until flowering period.
Perennial plants post flowering period, virtually all biological processes are allocated to the root development and nutrient accumulation in roots. The same tendency can be observed in certain genotypes of horseradish roots (Tomsone et al., 2012), where a higher content of phenolic compounds were directly in the post flowering stage. Pacifico et al. (2015) reported that quercetin derivative of areal parts of Calamintha nepeta L. Savi was significantly higher at the flowering stage than at the post flowering stage.

Antioxidant activity (AA)

Phenolic compounds have been reported to have strong AA (Li et al., 2006). The antioxidant potential of these biological active compounds is dependent on the structural conformation (Elzaawely et al., 2007). Results of multivariate dispersion analyses showed that harvest time is significant $(\mathrm{p}<0.05)$ factor affecting AA.

Scavenging activity of DPPH radicals for all samples has similar tendencies that the higher activity was in June, and during post flowering stage by October it gradually decreased by an average of $45 \%$. The highest $\mathrm{DPPH}^{-}$scavenging activity was determined in horseradish leaves in June 2016 (Table 4) similar to TFC. It allows thinking that exactly flavonoids of horseradish leaves have a high $\mathrm{DPPH}^{*}$ scavenging activity.

Table 3

Total flavonoid content of horseradish leaves at different harvest times, mg CE $100 \mathrm{~g}^{-1} \mathrm{DW}$

\begin{tabular}{llll}
\hline Harvest times & \multicolumn{1}{c}{$\mathbf{2 0 1 4}$} & $\mathbf{2 0 1 5}$ & \multicolumn{2}{c}{$\mathbf{2 0 1 6}$} \\
\hline May & $8515 \pm 223^{\mathrm{b}^{*}, \mathrm{~A}^{* *}}$ & $9192 \pm 237^{\mathrm{b}, \mathrm{B}}$ & $9087 \pm 229^{\mathrm{b}, \mathrm{A}, \mathrm{B}}$ \\
June & $11136 \pm 233^{\mathrm{a}, \mathrm{A}}$ & $11099 \pm 261^{\mathrm{a}, \mathrm{A}}$ & $11697 \pm 257^{\mathrm{a}, \mathrm{A}}$ \\
July & $7036 \pm 183^{\mathrm{c}, \mathrm{A}, \mathrm{B}}$ & $7409 \pm 245^{\mathrm{c}, \mathrm{B}}$ & $6873 \pm 199^{\mathrm{c}, \mathrm{A}}$ \\
August & $5486 \pm 211^{\mathrm{d}, \mathrm{A}}$ & $5038 \pm 253^{\mathrm{d}, \mathrm{A}}$ & $5070 \pm 226^{\mathrm{d}, \mathrm{A}}$ \\
September & $3921 \pm 230^{\mathrm{e}, \mathrm{A}}$ & $3518 \pm 245^{\mathrm{e}, \mathrm{A}}$ & $776 \pm 219^{\mathrm{e}, \mathrm{A}}$ \\
October & $2486 \pm 220^{\mathrm{f}, \mathrm{A}}$ & $2970 \pm 252^{\mathrm{e}, \mathrm{A}}$ & $2784 \pm 231^{\mathrm{f}, \mathrm{A}}$ \\
\hline
\end{tabular}

Table 4

DPPH$^{*}$ scavenging activity of horseradish leaves at different harvest times, $\mathrm{mM}$ TE $100 \mathrm{~g}^{-1} \mathrm{DW}$

\begin{tabular}{llcc}
\hline Harvest times & $\mathbf{2 0 1 4}$ & $\mathbf{2 0 1 5}$ & $\mathbf{2 0 1 6}$ \\
\hline May & $52.84 \pm 2.18^{\mathrm{b}^{*}, \mathrm{~A}, \mathrm{~B}, *}$ & $50.92 \pm 2.02^{\mathrm{b}, \mathrm{A}}$ & $57.41 \pm 2.31^{\mathrm{b}, \mathrm{B}}$ \\
June & $69.33 \pm 1.92^{\mathrm{a}, \mathrm{A}}$ & $71.09 \pm 2.11^{\mathrm{a}, \mathrm{A}}$ & $73.38 \pm 2.07^{\mathrm{a}, \mathrm{A}}$ \\
July & $51.69 \pm 2.27^{\mathrm{c}, \mathrm{A}}$ & $57.30 \pm 2.40^{\mathrm{c}, \mathrm{A}, \mathrm{B}}$ & $61.50 \pm 2.35^{\mathrm{b}, \mathrm{c}, \mathrm{B}}$ \\
August & $48.03 \pm 2.09^{\mathrm{c}, \mathrm{A}}$ & $49.66 \pm 1.89^{\mathrm{c}, \mathrm{A}}$ & $53.04 \pm 2.12^{\mathrm{c}, \mathrm{A}}$ \\
September & $43.74 \pm 1.95^{\mathrm{d}, \mathrm{A}}$ & $40.97 \pm 2.30^{\mathrm{d}, \mathrm{A}}$ & $45.53 \pm 2.28^{\mathrm{d}, \mathrm{A}}$ \\
October & $39.18 \pm 1.83^{\mathrm{d}, \mathrm{A}}$ & $39.51 \pm 1.75^{\mathrm{d}, \mathrm{A}}$ & $37.13 \pm 1.99^{\mathrm{e}, \mathrm{A}}$ \\
\hline
\end{tabular}

Table 5

$\mathrm{ABTS}^{\cdot+}$ scavenging activity of horseradish leaves at different harvest times, $\mathrm{mM}$ TE $100 \mathrm{~g}^{-1} \mathrm{DW}$

\begin{tabular}{llll}
\hline Harvest times & $\mathbf{2 0 1 4}$ & $\mathbf{2 0 1 5}$ & $\mathbf{2 0 1 6}$ \\
\hline May & $148.92 \pm 5.74^{\mathrm{a}^{*}, \mathrm{~A}^{* *}}$ & $150.83 \pm 5.44^{\mathrm{a}, \mathrm{A}}$ & $146.71 \pm 6.3^{\mathrm{a}, \mathrm{A}}$ \\
June & $140.08 \pm 4.99^{\mathrm{a}, \mathrm{A}}$ & $143.13 \pm 5.16^{\mathrm{a}, \mathrm{A}}$ & $142.52 \pm 3.69^{\mathrm{a}, \mathrm{A}}$ \\
July & $125.50 \pm 3.93^{\mathrm{b}, \mathrm{A}}$ & $127.70 \pm 3.65^{\mathrm{b}, \mathrm{A}}$ & $126.24 \pm 4.03^{\mathrm{b}, \mathrm{A}}$ \\
August & $121.44 \pm 4.34^{\mathrm{b}, \mathrm{c}, \mathrm{A}}$ & $122.20 \pm 4.47^{\mathrm{b}, \mathrm{c}, \mathrm{A}}$ & $124.24 \pm 5.25^{\mathrm{b}, \mathrm{A}}$ \\
September & $112.04 \pm 3.62^{\mathrm{c}, \mathrm{A}}$ & $111.63 \pm 3.03^{\mathrm{c}, \mathrm{A}}$ & $11.48 \pm 3.23^{\mathrm{c}, \mathrm{A}}$ \\
October & $91.76 \pm 2.98^{\mathrm{e}, \mathrm{B}}$ & $88.07 \pm 2.48^{\mathrm{d}, \mathrm{A}, \mathrm{B}}$ & $81.42 \pm 2.68^{\mathrm{d}, \mathrm{A}}$ \\
\hline
\end{tabular}

${ }^{*}$ Different small letters in the same column represents significant differences between values (Tukey's test, $\mathrm{p}<0.05$ ).

** Different capital letters in the same row represents significant differences between values (Tukey's test, $\mathrm{p}<0.05$ ). 
Reducing power of horseradish leaves at different harvest times, mg AAE $100 \mathrm{~g}^{-1} \mathrm{DW}$

\begin{tabular}{lllc}
\hline Harvest times & \multicolumn{1}{c}{$\mathbf{2 0 1 4}$} & $\mathbf{2 0 1 5}$ & $\mathbf{2 0 1 6}$ \\
\hline May & $8548 \pm 210^{\mathrm{b}^{*}, \mathrm{~A}^{* *}}$ & $7834 \pm 223^{\mathrm{b}, \mathrm{B}}$ & $7639 \pm 198^{\mathrm{b}, \mathrm{B}}$ \\
June & $9000 \pm 207^{\mathrm{a}, \mathrm{A}}$ & $9135 \pm 190^{\mathrm{a}, \mathrm{A}, \mathrm{B}}$ & $9573 \pm 192^{\mathrm{a}, \mathrm{B}}$ \\
July & $7990 \pm 187^{\mathrm{c}, \mathrm{B}}$ & $7437 \pm 216^{\mathrm{b}, \mathrm{A}}$ & $7576 \pm 205^{\mathrm{b}, \mathrm{A}, \mathrm{B}}$ \\
August & $5708 \pm 150^{\mathrm{d}, \mathrm{A}}$ & $5532 \pm 178^{\mathrm{c}, \mathrm{A}}$ & $5457 \pm 161^{\mathrm{c}, \mathrm{A}}$ \\
September & $4621 \pm 197^{\mathrm{e}, \mathrm{B}}$ & $3691 \pm 209^{\mathrm{d}, \mathrm{A}}$ & $3981 \pm 176^{\mathrm{d}, \mathrm{A}}$ \\
October & $2873 \pm 165^{\mathrm{f}, \mathrm{A}}$ & $2638 \pm 176^{\mathrm{e}, \mathrm{A}}$ & $2998 \pm 190^{\mathrm{e}, \mathrm{A}}$ \\
\hline
\end{tabular}

* Different small letters in the same column represents significant differences between values (Tukey's test, $\mathrm{p}<0.05)$.

${ }^{* *}$ Different capital letters in the same row represents significant differences between values (Tukey's test, $\left.\mathrm{p}<0.05\right)$.

The same tendency was observed with Calamintha nepeta L. Savi where an antioxidant potential $\left(\mathrm{DPPH}^{*}\right)$ decreased during the post flowering stage (Pacifico et al., 2015).

The highest ABTS $^{+}$scavenging activity was determined in horseradish leaves in May 2015 (Table 5), similar to TPC. Apparently other phenolic compounds fractions (not flavonoids) have a way of better scavenging activity of $\mathrm{ABTS}^{\cdot+}$. The highest $\mathrm{ABTS}^{\circ}$ scavenging activity was in May for all analysed samples and by October it gradually decreased on average by $41 \%$.

Imene et al. (2012) reported about scavenging activity depending on the harvest time - as chemical composition, amounts and nature of compounds vary within development stages and species; it can be influenced by changes in secondary metabolism. AA shows a marked variation with ontogenic growth stages and the maximum of AA is observed during post flowering stage for the two species - Opuntia ficusindica (L.) Mill. and O. stricta (Haw.) Haworth (Imene et al., 2012). It is the opposite trend by horseradish leaves AA and areal parts of Calamintha nepeta L. Savi (Pacifico et al., 2015).

Reducing power (RP) associated with indirect antioxidants and it can serve as a significant reflection of activities (Oktay et al., 2003). Literature reports show that antioxidant activity of plant and herb is related to the reducing power that interrupts radical chain reactions (Singh, Rajini, 2004). The existence of reductants is key to reducing power, which shows the antioxidant activity because donate hydrogen atoms and interrupt free radical chain reactions (Xing et al., 2005).

The experiments showed that reducing power is dependent on the plant harvest time. The highest reducing power was determined in June 2016 (Table 6), similar to TFC. It is considered that in plant material poor in vitamin $\mathrm{C}$, main antioxidants are flavonoids and phenolic acids (Igual et al., 2012). Apparently horseradish leaves flavonoids are able to donate hydrogen atoms by interrupting free radical chain reactions.

As mentioned above, higher reducing power was in June, and by October (during post flowering stage) it gradually decreased by an average of $69 \%$. It can be explained by the modification of chemical composition of horseradish leaves in the post flowering stage. The antioxidant potential (reducing power) of areal parts of Calamintha nepeta L. Savi was significantly higher at the flowering stage than at the post flowering stage (in October) (Pacifico et al., 2015).

The results show that pre-flowering and flowering stages corresponds to the maximum accumulation of phenolic compounds and antioxidant activities.

Correlation between phenolic content and antioxidant activity (AA)

The AA is influenced by the phenolic composition. A various correlation coefficients were obtained by analysing relationship between phenolics compounds and AA in. Overall, positive strong correlation between TPC, TFC, DPPH ${ }^{\circ}$, ABTS $^{-+}$and reducing power was determined. This can be explained by the fact that phenolic compounds are the most important antioxidant of horseradish leaves. Further research is necessary to identify individual phenolic compounds and analyse their influence on the overall free radical scavenging activity.

Prasad et al. (2009) found, that statistical correlations between TPC and total antioxidant capacity of litchi seed were strong $(r=0.98)$, that is similar to results of the current research. But Pacifico et al. (2015) found that correlation between TPC and $\mathrm{ABTS}^{\circ+}$ scavenging activity of areal parts of Calamintha nepeta L. Savi were moderate $(\mathrm{r}=0.64)$. Whereas stronger correlation between TFC - DPPH ${ }^{\circ}$ and TFC - reducing power was observed in June ( $\mathrm{r}=0.861$ and $\mathrm{r}=0.853$, respectively). Strong correlation between phenolic compounds and AA was also found in seabuckthorn (Hippohae rhamnoides L.) leaves (Kumar et al., 2011), canola meal (Hassas-Roudsari et al., 2009) and lychee (L. chinenesis Sonn.) flowers (Liu et al., 2009). It coincides with the highest concentration and activity of these compounds. The correlation ranged from medium to weak at the others harvest times. Fresh L. lucidus Turcz. roots were harvested at three different times and there was significant correlation between phenolic content and different antioxidant assays (Lu et al., 2015).

\section{Conclusions}

This research is contribution to the determination of the content of phenolic compounds in horseradish leaves and its variability depending on the harvest time. Results showed that content of phenolic compounds and antioxidant activity was significantly affected both 
by harvest time and year. The highest TPC and $\mathrm{ABTS}^{++}$ was observed in the horseradish leaves collected in the May, but TFC, DPPH ${ }^{-}$and reducing power - in the plants collected in June. The content of phenolics compounds and antioxidant activity significantly decreased during post flowering stage and continued till October. Horseradish leaves contained considerable content of phenolics compounds and natural antioxidants. Also a strong correlation between the TPC and $\mathrm{ABTS}^{-+}$as well as TFC and $\mathrm{DPPH}^{*}$, reducing power at harvest time in May was detected. Further experiments are necessary to evaluate antioxidant activity of horseradish leaves extracts in food matrixes.

\section{Acknowledgment}

Research has been supported by the National research programme "Agricultural Resources for Sustainable Production of Qualitative and Healthy Foods in Latvia" (AgroBioRes) (2014-2017), project No. 4 "Sustainable use of local agricultural resources for qualitative and healthy food product development" (FOOD).

\section{References}

1. Angela M., Meireles A. (2009). Extracting Bioactive Compounds for Food Products Theory and Applications. Boca Raton, EUA: CRC Press Taylor \& Francis Group. 466 p.

2. Athukorala Y., Kim K.N., Jeon Y.J. (2006) Antiproliferative and antioxidant properties of an enzymatic hydrolysate from brown alga, Ecklonia cava. Food and Chemical. Toxicology, Vol. 44, p. 1065-1074.

3. Björkman M., Klingen I., Birch A. N.E., Bones A.M., Bruce T.J.A., Johansen T.J., Meadow R., Mølmann J., Seljåsen R., Smart L.E., Stewart D. (2011) Phytochemicals of Brassicaceae in plant protection and human health - Influences of climate, environment and agronomic practice. Phytochemistry, Vol. 72, p. 538-556.

4. Calabrone L., Larocca M., $\quad$ Marzocco S., Martelli G. (2015) Total phenolis and flavonoids content, antioxidant capacity and lipase inhibition if root and leaf horseradish (Armoracia rusticana) extracts. Food and Nutrition Science, Vol. 6, p. 64-74.

5. Capanoglu E. (2010) The potential of priming in food production. Trends in Food Science and Technology, Vol. 21, p. 399-407.

6. Elzaawely A.A., Xuan T.D., Koyama H., Tawata S. (2007) Antioxidant activity and contents of essential oil and phenolic compounds in flowers and seeds of Alpinia zerumbet (Pers.) B. L. Burtt. and R.M. Sm. Food Chemistry, Vol. 104, p. 1648-1653.

7. Fernando I.D.N.S., Abeysinghe D.C., Dharmadasa R.M. (2013) Determination of phenolic contents and antioxidant capacity of different parts of Withania somnifera (L.) Dunal. from three different growth stages. Industrial Crops and Products, Vol. 50, p. 537-539.

8. Gould K.S., Lister C. (2006) Flavonoid Functions in Plants. In Ø.M. Andersen, K. R. Markham (Eds.) Flavonoids Chemistry, Biochemistry and Applications (p. 397-441).Boca Raton FL: CRC Press Taylor \& Francis Group LLC.

9. Hassas-Roudsari M., Chang P.R., Pegg R.B., Tyler R.T. (2009) Antioxidant capacity of bioactives extracted from canola meal by subcritical water, ethanolic and hot water extraction. Food Chemistry, Vol. 114, p. 717-726.
10. Hilt P., Schieber A., Yildirim C., Arnold G., Klaiber I., Conrad J., Beifuss U., Carle R. (2003) Detection of phloridzin in strawberries (Fragaria $x$ ananassa Duch.) by HPLC-PDA-MS/MS and NMR spectroscopy. Journal of Agricultural and Food Chemistry, Vol. 51, p. 2896-2899.

11. Igual M., García-Martínez E., Martín-Esparza M.E., Martínez-Navarrete N. (2012) Effect of processing on the drying kinetics and functional value of dried apricot. Food Research International, Vol. 47, p. 284-290.

12. Imene A., Monia E., Bassem K., Thabet Y., Hamadi A. (2012) Variation in chemical composition and biological activities of two species of Opuntia flowers at four stage of flowering. Industrial Crops and Products, Vol. 37, p. 34-40.

13. Kammerer D. R., Kramer M., Carle R. (2012) Chapter 21. Phenolic Compounds. In: Food Analysis by HPLC. Edited by: L. M. L. Nollet, F. Toldra. 3rd edition. Boca Raton, FL: CRC Press, p. 717-756.

14. Kim D., Jeong S.W., Lee C.Y. (2003) Antioxidant capacity of phenolic phytochemicals from various cultivars of plums. Food Chemistry, Vol. 81, p. 321-326.

15. Kumar M.S.Y., Dutta R., Prasad D., Misra K. (2011) Subcritical water extraction of antioxidant compounds from Seabuckthorn (Hippophae rhamnoides) leaves for the comparative evaluation of antioxidant activity. Food Chemistry, Vol. 127(3), p. 1309-1316.

16. Kusznierewicz B., Bartoszek A., Wolska L., Drzewiecki J., Gorinstein S., Namieśnik J. (2008) Partial characterization of white cabbages (Brassica oleracea var. capitata f. alba) from different regions by glucosinolates, bioactive compounds, total antioxidant activities and proteins. LWT - Food Science and Technology, Vol. 41, p. 1-9.

17. Li B.B., Smith B., Hossain Md. M. (2006) Extraction of phenolics from citrus peels I. Solvent extraction method. Separation and Purification Technology, Vol. 48, p. 182-188.

18. Liu S.C., Lin J.T., Wang C.K., Chen H.Y., Yang D.J. (2009) Antioxidant properties of various solvent extracts from lychee (Litchi chinenesis Sonn.) flowers. Food Chemistry, Vol. 114, p. 577-581.

19. Lu Y-h., Huang J-h., Li Y-c., Ma T-t., Sang P., Wang W-j., Gao C-y. (2015) Variation in nutritional compositions, antioxidant activity and microstructure of Lycopus lucidus Turcz. root at different harvest times. Food Chemistry, Vol. 183, p. 91-100.

20. Marrelli M., Menichini F., Statti G.A., Bonesi M., Duez P., Menichini F., Conforti F. (2012) Changes in the phenolic and lipophilic composition, in the enzyme inhibition and antiproliferative activity of Ficuscarica L. cultivar Dottato fruits during maturation. Food and Chemical Toxicology, Vol. 50, p. 726-733.

21. Naczk M., Shahidi F. (2003) Antioxidant Properties of Food Phenolics. In M. Naczk, \& F. Shahidi (Eds.), Phenolics in Food and Nutraceuticals (pp.1-40). Boca Raton, FL: CRC Press.

22. Naczk M., Shahidi F. (2006) Phenolic in cereals, fruit and vegetables: Occurrence, extraction and analysis. Journal of Pharmaceutical and Biomedical Analysis, Vol. 41(5), p. $1523-1542$.

23. Oktay M., Gulcin I., Kufrevioglu O. I. (2003) Determination of in vitro antioxidant activity of fennel (Foeniculum vulgare) seed extracts. Lebanon-Wissen Technologies, Vol. 36, p. 263-271.

24. Pacifico S., Galasso S., Piccolella S., Kretschmer N., Pan S.-P., Marciano S., Bauer R., Monaco P. (2015) Seasonal 
variation in phenolic composition and antioxidant and anti-inflammatory activities of Calamintha nepeta (L.) Savi. Food Research International, Vol. 69, p. 121-132.

25. Prasad K.N., Yang B., Yang S., Chen Y., Zhao M., Ashraf M., Jiang Y. (2009) Identification of phenolic compounds and appraisal of antioxidant and antityrosinase activities from litchi (Litchi sinensis Sonn.) seeds. Food Chemistry, Vol. 116(1), p. 1-7.

26. Raghavan Uhl S. (2000) Handbook of Spices, Seasonings, and Flavorings. Boca Raton: Technomic Publishing, Lancaster, $352 \mathrm{p}$.

27. Re R., Pellegrini N., Proteggente A., Pannala A., Yang M., Rice-Evans C. (1999) Antioxidant activity applying an improved ABTS radical cation decolorization assay. Free Radical Biology and Medicine, Vol. 26, p. 1231-1237.

28. Singh N., Rajini P. S. (2004) Free radical scavenging activity of an aqueous extract of potato peel. Food Chemistry, Vol. 85, p. 611-616.

29. Singleton V.L., Orthofer R., Lamuela-Raventos R.M. (1999) Analysis of total phenols and other oxidation substrates and antioxidants by means of Folin-Ciocalteu reagent. Methods in Enzymology, Vol. 29, p. 152-178.

30. Tomsone L., Kruma Z., Lepse L. (2012) Influence of genotype and harvest time on the phenolic content of horseradish (Armoracia rusticana L.) roots. In: Research for rural development 2012: Annual 18th international scientific conference proceedings, Jelgava, 16-18 May 2012 / Latvia University of Agriculture. Jelgava: LLU, Vol. 1, p. 124-130.

31. Zhou K., Yu L. (2006) Total phenolic contents and antioxidant properties of commonly consumed vegetables grown in Colorado, LWT - Food Science and Technology, Vol. 39, p. 1155-1162.

32. Xing R., Yu H. H., Liu S., Zhang W. W., Zhang Q. B., LiZ. E. (2005) Antioxidant activity of differently regioselective chitosan sulfates in vitro. Bioorganic \& Medicinal Chemistry, Vol. 13, p. 1387-1392.

33. Yu L., Haley S., Perret J., Harris M., Wilson J., Haley S. (2003) Antioxidant properties of bran extracts from Akron wheat grown at different locations. Journal of Agriculture and Food Chemistry, Vol. 51, p. $1566-1570$. 